\title{
Drying Parameters of Half-Cut and Ground Figs (Ficus carica L.) var. Mission and the Effect on Their Functional Properties
}

\author{
Juan José Martínez-García, ${ }^{1,2}$ José Alberto Gallegos-Infante, ${ }^{1}$ \\ Nuria Elizabeth Rocha-Guzmán, ${ }^{1}$ Patricia Ramírez-Baca, ${ }^{2}$ \\ María Guadalupe Candelas-Cadillo, ${ }^{2}$ and Rubén Francisco González-Laredo ${ }^{1}$ \\ ${ }^{1}$ Unidad de Posgrado, Investigación y Desarrollo Tecnológico (UPIDET), Instituto Tecnológico de Durango, \\ Felipe Pescador 1830 Oriente, 34080 Durango, DGO, Mexico \\ ${ }^{2}$ Facultad de Ciencias Químicas, Universidad Juárez del Estado de Durango (UJED), Campus Gómez Palacio, \\ Artículo 123 s/n Fraccionamiento Filadelfia, 35010 Gómez Palacio, DGO, Mexico
}

Correspondence should be addressed to Rubén Francisco González-Laredo; gonzalezlaredo@gmail.com

Received 29 November 2012; Accepted 16 January 2013

Academic Editor: Navin K. Rastogi

Copyright (c) 2013 Juan José Martínez-García et al. This is an open access article distributed under the Creative Commons Attribution License, which permits unrestricted use, distribution, and reproduction in any medium, provided the original work is properly cited.

\begin{abstract}
Drying of ground and half-cut figs (Ficus carica L., var. Mission) was investigated at three temperatures $\left(45,55\right.$, and $65^{\circ} \mathrm{C}$ ). Their effective moisture diffusivity $\left(D_{\text {eff }}\right)$ was estimated by using the slope method. $D_{\text {eff }}$ values for ground figs were $5.15 \times 10^{-10}$, $9.96 \times 10^{-10}, 1.07 \times 10^{-9} \mathrm{~m}^{2} \mathrm{~s}^{-1}$ and for half cut figs $5.88 \times 10^{-10}, 1.66 \times 10^{-9}$, and $2.08 \times 10^{-9} \mathrm{~m}^{2} \mathrm{~s}^{-1}$ at 45,55 , and $65^{\circ} \mathrm{C}$, respectively. Dehydrating fig samples showed a similar behavior: higher $D_{\text {eff }}$ values at higher temperatures and activation energy $\left(E_{a}\right)$ values in the range of other foodstuffs. Half-cut figs needed about twice more energy and time than ground figs to carry out the dehydration; $E_{a}$ values were 56.86 and $28.21 \mathrm{~kJ} \mathrm{~mol}^{-1}$, respectively. The drying process increased the total phenolic content and degraded the anthocyanin content of figs; however, it enhanced the dried figs antioxidant activity. Dehydrating ground figs was faster and maintained its functional properties better than half-cut figs.
\end{abstract}

\section{Introduction}

Many studies have demonstrated that daily intake of fruit and vegetable is associated with the reduction of chronicdegenerative diseases $[1,2]$. In other investigations, it has been observed that fruit- and vegetable- rich diets protect against different diseases, including cancer and cardiovascular diseases. Etiology for these diseases is pointing to the free radicals as promoters of protein, nucleic acids, and cellular lipids oxidations that damage biological systems; fruits and vegetables contain a great number of components with antioxidant activity, such as flavonoids, carotenoids, and vitamins $\mathrm{C}$ and $\mathrm{E}$ [3].

Nowadays, the study for different vegetables species is promoted in order to identify their diverse functional capacities; since the human organism cannot produce phytochemicals such as polyphenols, they have to be obtained from food [4]. The most viable alternative is to consume fresh fruit and vegetables, since it is well known that after harvesting, their components can change during processing and storage and relatively lose part of its biological activity. Although there are some factors that can limit its intake such as seasonal availability, market accessibility, cost, and shelf life, it is important to process them by freezing, canning, or drying, but these conservation methods can reduce the bioactive component contents [5].

Fig tree (Ficus carica L.) is widely found in tropical and subtropical countries, and its fruit has a high commercial value. Fig production is mainly located around the Mediterranean Sea or in places with similar weather such as California, Australia, or South America [6]. From the yearly world production of fruits of above 600 million tons, fig is over one million tons. The largest fig producer is Turkey with about $23.5 \%$ of the total world harvest. The 
$51.6 \%$ of this production is commercialized as dry fruit [7].

Today, fig is a remarkable world crop due to its consumption as a fresh or dry fruit. Besides, it has been demonstrated that figs are an important source of minerals and vitamins such as iron, calcium, potassium, thiamin, and riboflavin. Figs are sodium, fat, and cholesterol free; they contain at least 17 amino acids, having aspartic and glutamic acids as the highest in concentration. Fig contains a relatively high content of fiber $(5.8 \% \mathrm{w} / \mathrm{w})$, and more than $28 \%$ of it is soluble; so, it helps to control blood sugar and cholesterol and to reduce weight [8]. Dried figs have the highest polyphenol concentration when they are compared with regular fruits and beverages generally consumed [9]. For all those features, figs are genuinely considered as functional foods [10].

However, fig is very sensitive to microbial growth even under cold storage; thus, it is important to consider alternative processes to extend its shelf life. Figs may be processed in low-cost convective dryers due to their effectiveness and simplicity [11]. Convective drying kinetics is affected by many factors, such as fig size and composition and thermodynamics properties of drying air such as temperature, humidity, and velocity. With drying, fig mass and volume are reduced, as well as packaging and handling costs. It also reduces the microbiological activity and chemical changes during storage of the final dehydrated product.

Examples of recent studies on drying modeling include food products such as onion [12], persimmon slices [13], jujube fruit [14], pomegranate seeds [15], and olive pomace drying [16]. Although drying models for whole figs [17-19], peeled figs [20], and longitudinally cut figs [21] have been reported, there are no studies on ground or half-cut figs var. Mission and the effect of the drying process on the fruit functional properties. Therefore, the aim of this investigation was to identify in which way drying temperature and fruit appearance (i.e., size and shape) affect fig functional properties and to calculate fig drying parameters such as effective diffusivity and activation energy, applying analytical solutions to Fick's equation and the Arrhenius relationship. These parameters are necessary for an efficient fig dryer design and for optimizing the drying process itself.

\section{Materials and Methods}

2.1. Tray Dryer Characteristics. The figs were dehydrated in an electric tray drier, developed at Facultad de Ciencias Químicas, UJED, at Gómez Palacio, Durango, Mexico. The drier includes a $30 \mathrm{~cm}$ diameter fan, four electric heaters, and a digital balance with $0.1 \mathrm{~g}$ sensitivity (Denver Instrument XP3000), and it is equipped with temperature and air velocity controls (Figure 1). Total length of dryer is $1.20 \mathrm{~m}$; the cabinet has three Teflon $25 \times 25 \mathrm{~cm}$ perforated mesh plates $(5 \mathrm{~mm})$. Drying conditions (wet bulb temperature, air temperature, and air velocity) were automatically controlled.

2.2. Sample Preparation and Drying Conditions. Fresh figs (Ficus carica L.) var. Mission were collected during 2010 harvesting season at Ejido Alvaro Obregon, Lerdo, Durango,

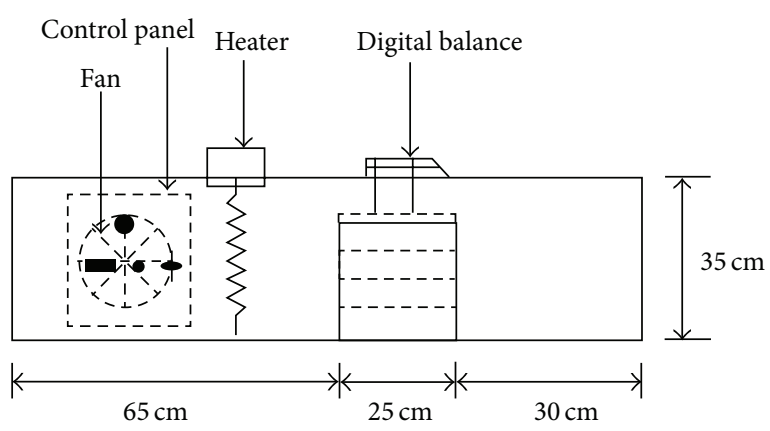

FIGURE 1: Scheme of the thin-layer drying equipment used.

Mexico. Their initial length and diameter were estimated measuring manually 20 figs with a vernier caliper. Figs were water washed and disinfected with chlorine, previous to their drying. Two sample appearances (size and shapes) were tested: ground figs and cut figs in longitudinal halves. For the first case, a grind was used (Grind-O-matic, Rival Mfg. Co.) and the ground fig forced to pass a $4 \mathrm{~mm}$ screen; for the second, figs were chosen at homogeneous sizes and manually cut longitudinally with a knife. Ground figs were set in the trays as a layer of $5 \mathrm{~mm}$ thickness, while half-cut figs were set cut face up. Drying temperature was set at 45,55 , and $65^{\circ} \mathrm{C}$. The air velocity was maintained constant at $1.4 \mathrm{~m} \mathrm{~s}^{-1}$, and the drying process was considered completed when fig samples have not shown weight changes, which was monitored within regular intervals. Dry weight for each sample was determined at $70^{\circ} \mathrm{C}$ during $24 \mathrm{~h}$ [22]. Fresh fig samples were freeze dried (Labconco Model 7400030) at 0.05 mbar and $-40^{\circ} \mathrm{C}$. All determinations were carried out by triplicate.

\subsection{Drying Data Analysis}

2.3.1. Determination of Effective Diffusivity. The effective diffusivity of fig was estimated by using the simplified mathematical Fick's second model. Analytical solution of onedimensional Fick's law of diffusion with constant moisture diffusivity for a sphere is given by Crank [23] as

$$
\mathrm{MR}=\frac{6}{\pi^{2}} \sum \frac{1}{n^{2}} \exp \left(-\frac{n^{2} \pi^{2} t D_{\mathrm{eff}}}{r^{2}}\right),
$$

where MR is the moisture ratio, $D_{\text {eff }}$ is the effective moisture diffusivity $\left(\mathrm{m}^{2} \mathrm{~s}^{-1}\right)$, and $r$ is the median radius of the fig. At longer drying times (setting $n=1$ ), (1) can be simplified to a straight-line relationship according to Riva and Peri [24] as follows:

$$
\ln (\mathrm{MR}) \approx \ln \left(\frac{6}{\pi^{2}}\right)-\left(\frac{\pi^{2} t D_{\mathrm{eff}}}{r^{2}}\right) .
$$

The effective moisture diffusivity was calculated using the slope method. Effective diffusivities are typically determined by plotting experimental drying data in terms of moisture rate (MR) versus time data. From (2), a plot of $\ln (\mathrm{MR})$ versus time 
gives a straight line with slope $\left(k_{2}\right)$, as was modeled for halfcut figs by Babalis and Belessiotis [25], where

$$
k_{2}=\left(\pi^{2}\right) \frac{D_{\mathrm{eff}}}{r^{2}} .
$$

For ground figs, $D_{\text {eff }}$ was calculated considering them as an infinite plate of thickness $L$, dried from one side of the fruit thin layer according to the following [26]:

$$
k_{2}=\left(\pi^{2}\right) \frac{D_{\mathrm{eff}}}{4 L^{2}} .
$$

For both equations, slope value $\left(k_{2}\right)$ was calculated with a natural logarithm graphic of moisture ratio (MR) with respect to time. $L$ is the dry fig coat thickness for ground fig, and $r$ is the radius of half-cut figs.

Activation energy may be calculated by an Arrheniustype equation such as the following

$$
\begin{gathered}
\ln D=\left(\frac{\Delta E}{R_{g}}\right) \frac{1}{T}+C, \\
D_{\text {eff }}=D_{0} \exp \left(-\frac{E_{a}}{R_{g} T}\right),
\end{gathered}
$$

where $E_{a}$ is the diffusion activation energy $\left(\mathrm{J} \mathrm{mol}^{-1}\right) ; D_{\text {eff }}$ is the effective moisture diffusivity coefficient $\left(\mathrm{m}^{2} \mathrm{~s}^{-1}\right) ; R_{g}$ is the universal gas constant; $T$ is the absolute temperature $\left({ }^{\circ} \mathrm{K}\right)$. When plotting $\ln \left(D_{\text {eff }}\right)$ versus $1 / T$, a straight line is obtained, whose slope corresponds to $E_{a} / R_{g}$, while the $y$ intercept value is $\ln \left(D_{0}\right)$.

\subsection{Functional Properties}

2.4.1. Extract Preparation. Figs were homogenized in a blender for $30 \mathrm{~s}$. Acidified methanol (25 mL) containing 0.5\% trifluoroacetic acid (TFA) was added to a blended fig sample $(3.5 \mathrm{~g})$ and placed on an ultrasonic bath (Branson 3510) for $30 \mathrm{~min}$, and after that, it was frozen at $-18^{\circ} \mathrm{C}$ for $16 \mathrm{~h}$. Next, they were centrifuged for $20 \mathrm{~min}$ at 7,000 rpm in a refrigerated centrifuge at $4^{\circ} \mathrm{C}$. This process was repeated two times every four hours, until the complete extraction was obtained after $24 \mathrm{~h}$. Extracts were combined and vacuum concentrated to the complete removal of methanol.

2.4.2. Total Phenolic Content (TPC). Folin-Ciocalteu method was applied to determine the total phenolic content of figs using a UV/VIS Hach spectrophotometer DR 4000 [27]. The results were expressed as mg equivalent of catechin (CE) per gram of dried fruit.

2.4.3. Polymeric Color Analysis. Percentage of polymeric color was determined using the method described by Giusti and Wrolstad [28].

2.4.4. Total Anthocyanin Content. Total anthocyanin content was calculated as equivalents of cyanidin-3-glucoside and evaluated by the $\mathrm{pH}$ differential method [28], using two buffer systems: potassium chloride buffer, $\mathrm{pH} 1.0(0.025 \mathrm{M})$, and sodium acetate buffer, pH $4.5(0.4 \mathrm{M})$. A $0.2 \mathrm{~mL}$ fig extract aliquot was placed in an assay tube and added $6 \mathrm{~mL}$ buffer ( $\mathrm{pH}$ 1.0) and mixed. A second aliquot was placed in another assay tube and added with the $4.5 \mathrm{pH}$ buffer. Both solutions were left at room temperature for $20 \mathrm{~min}$ before reading their absorbance in the spectrophotometer at 531 and $700 \mathrm{~nm}$, and the net absorbance calculated as follows:

$$
A=\left(A_{531}-A_{700}\right)_{\mathrm{pH} 1.0}-\left(A_{531}-A_{700}\right)_{\mathrm{pH} 4.5^{\circ}} .
$$

With the cyanidin-3-glucoside extinction coefficient of 26900 and its molecular weight of 449.2, anthocyanin content was estimated as mg of cyanidin-3-glucoside per $100 \mathrm{~g}$ dry weight.

2.4.5. Degradation Index (DI). It is defined as the parameter of the total (degraded and not degraded) anthocyanin, determined by the simple $\mathrm{pH}$ method [29], divided by the nondegraded anthocyanin, measured by the $\mathrm{pH}$ differential method [30], reading absorbances from fig extracts diluted with $\mathrm{pH} 1.0$ and $\mathrm{pH} 4.5$ buffers. Consider

$$
\mathrm{DI}=\frac{A_{\mathrm{pH} 1.0}}{\left(A_{\mathrm{pH} 1.0}-A_{\mathrm{pH} 4.5}\right)} .
$$

Calculating DI this way is suitable to determine anthocyanin degradation when no identified anthocyanin is present or if its extinction coefficient is unknown [31].

\subsubsection{Antioxidant Activity}

DPPH (2,2-Diphenyl-1-Picrylhydrazyl) Radical Scavenging Activity. The free radical scavenging activity of fig samples was measured according to Xiao-Ming et al. [32]. Briefly, a sample solution $(200 \mu \mathrm{L})$ was mixed with $1800 \mu \mathrm{L} 0.2 \mathrm{mM}$ DPPH-ethanol solution, and the absorbance of the sample solution $\left(A_{\text {sample }}\right.$ ) was measured at $515 \mathrm{~nm}$ against a blank after 30 min. The absorbance of the DPPH-ethanol solution $\left(A_{\mathrm{DPPH}}\right)$ was also measured at $515 \mathrm{~nm}$. The capability to scavenge the DPPH radical was calculated as follows:

$$
\begin{aligned}
& \mathrm{DPPH} \text { radical scavenging activity }(\%) \\
& \quad=\left[\frac{\left(A_{\mathrm{DPPH}}-A_{\text {sample }}\right)}{A_{\mathrm{DPPH}}}\right] \times 100 .
\end{aligned}
$$

The standard curve was prepared using different trolox concentrations $(120-960 \mu \mathrm{M})$. Each trolox dilution or fig extract samples $(200 \mu \mathrm{L})$ were added to DPPH solution aliquots $(1800 \mu \mathrm{L})$ and read at $515 \mathrm{~nm}$. All experiments were performed by triplicate. Results were expressed as $\mu \mathrm{M}$ equivalents of trolox per gram of dry fig and as the median effective concentration $\left(\mathrm{EC}_{50}\right)$.

ABTS Radical Scavenging Activity. This method [33] is based on the ability of antioxidants from fig to quench the long-lived ABTS radical cation (2,2' -azino-bis(3-ethylbenzthiazoline-6sulfonic acid), a blue/green chromophore with characteristic 
absorption at $734 \mathrm{~nm}$, in comparison with trolox, a watersoluble $\alpha$-tocopherol analogue. The ABTS+ was produced by the reaction of $2 \mathrm{mM}$ ABTS in $\mathrm{H}_{2} \mathrm{O}$ with $2.45 \mathrm{mM}$ potassium persulfate $\left(\mathrm{K}_{2} \mathrm{~S}_{2} \mathrm{O}_{8}\right)$, stored in the dark at room temperature for 16 hours. Before usage, the ABTS+ solution was diluted to get an absorbance of $0.750 \pm 0.025$ at $734 \mathrm{~nm}$ with ethanol. Then, different volumes of fig extracts $(100-200 \mu \mathrm{L})$ were added with $2 \mathrm{~mL}$ of ABTS+ solution. After six minutes, the percentage inhibition of ABTS at $734 \mathrm{~nm}$ was calculated for each concentration relative to a blank absorbance. The addition of an antioxidant reduced ABTS + to its colourless form. Solvent blanks were run in each assay. For preparation of a standard curve, different concentrations of trolox $(\mu \mathrm{M})$ were used. The concentration $(\mu \mathrm{M})$ in the reaction for each example was calculated from the calibration curve. Results were expressed as $\mu \mathrm{M}$ equivalents of trolox per gram of dry fig and as the median effective concentration $\left(\mathrm{EC}_{50}\right)$.

SDS-Modified Ferricyanide/Prussian Blue Method. Method by Işil Berker et al. [34] is faster and cheaper than the FRAP technique. A sample solution of $x \mathrm{~mL}$ was added with $(1-x) \mathrm{mL}$ of $96 \%$ ethanol, $6.3 \mathrm{~mL}$ of water, $0.2 \mathrm{~mL}$ of $\mathrm{HCl} 1 \mathrm{M}, 1.5 \mathrm{~mL}$ of ferricyanide solution (1\%), $0.5 \mathrm{~mL}$ of sodium dodecyl sulfate (SDS) (1\%), and finally, $0.5 \mathrm{~mL}$ of $\mathrm{FeCl}_{3} \cdot 6 \mathrm{H}_{2} \mathrm{O}(0.2 \%)$ to complete $10 \mathrm{~mL}$. Absorbance was read at $750 \mathrm{~nm}$ after $30 \mathrm{~min}$ at still and room temperature. A blank was prepared without sample, and a calibration curve was built using different concentrations of Trolox. Results were expressed as $\mu \mathrm{M}$ equivalents of trolox per gram of dry fig.

\section{Results and Discussion}

Figs were measured (length $3.51 \pm 0.20$, wide $4.07 \pm 0.09 \mathrm{~cm}$, and mean cross-section $11.24 \pm 0.73 \mathrm{~cm}^{2}$ ), cleaned, and their initial moisture content determined $(78.06 \pm 0.4 \%)$. Figures 2 and 3 show the drying curves for the applied treatments. It can be observed shorter dehydration times for the ground fig than the half-cut figs. In fact, total drying time for halfcut figs was about twice the required for ground figs, which may be explained by the relative exposition area per sample weight of each setting. In both cases the shortest dehydration time takes place at the highest temperature; so, this behavior suggests as expected that the process is proportional to the temperature used, with shorter times in this case at $65^{\circ} \mathrm{C}$.

From the drying curves of this experiment, it was observed that the convective drying of figs takes place predominantly in the falling rate period for the entire range of temperatures at the tested air velocity as was also noted previously by Babalis et al. [21]. The drying kinetics is most significantly affected by temperature, with the airflow velocity having a limited influence on the drying process as was shown by Babalis and Belessiotis [25].

It can also be observed similar data for dried figs at $55^{\circ}$ and $65^{\circ} \mathrm{C}$ for longitudinally half-cut figs, as reported previously [25] with reference to the time needed for drying fig halves at $65^{\circ} \mathrm{C}$. However, their data at constant drying period for

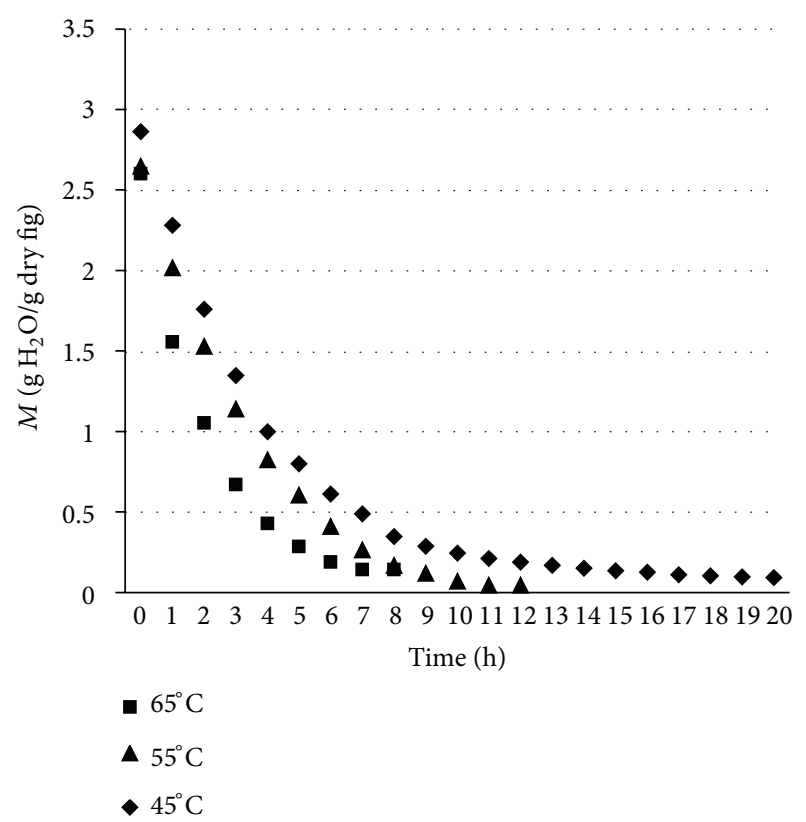

FIGURE 2: Effect of different temperatures in drying of ground fig (final moisture contents $9.8 \pm 1.5,4.9 \pm 1.1$, and $8.0 \pm 2.8 \%$ at $45^{\circ}, 55^{\circ}$, and $65^{\circ} \mathrm{C}$, resp.).

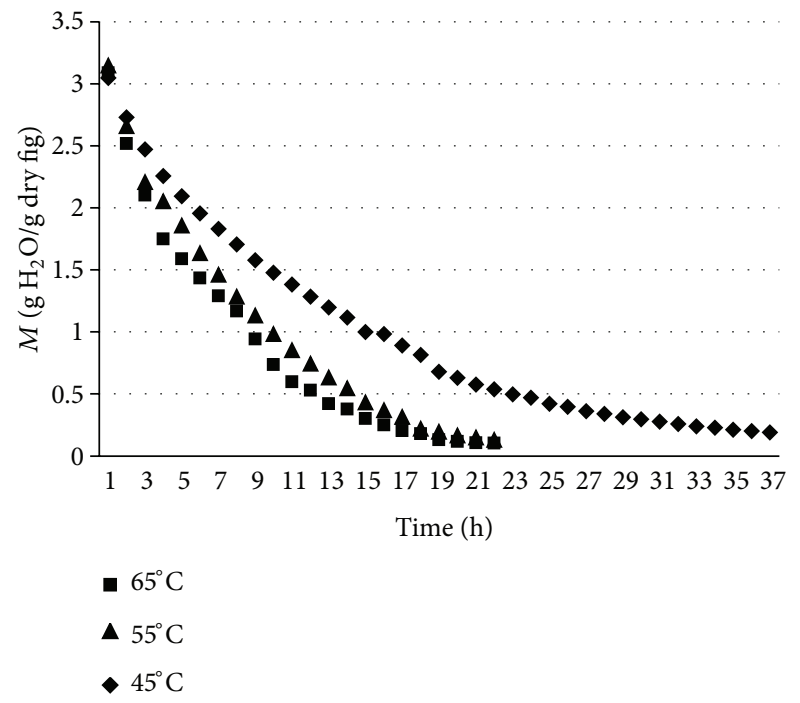

FIGURE 3: Effect of different temperatures in drying of half-cut figs (final moisture contents $14.3 \pm 4.2,10.7 \pm 4.7$, and $6.3 \pm 2.8$ at $45^{\circ}$, $55^{\circ}$, and $65^{\circ} \mathrm{C}$, resp.).

fruits is very short or does not exist; so, results are similar to those reported in the literature for carrots [35] and white onions slices [36], where dehydration index increments at higher temperatures.

The effective diffusivity for moisture $\left(D_{\text {eff }}\right)$ was calculated according to Lomauro et al. [37], Akpinar [38], and Doymaz $[39,40]$, using (1) and (2) with the natural logarithm slope (MR) and time. Calculated values for $D_{\text {eff }}$ at the different 
TABLE 1: Effective moisture diffusivity, $D_{\text {eff }}\left(\mathrm{m}^{2} \mathrm{~s}^{-1}\right)$, for dehydrated ground figs and half cut figs at different temperatures.

\begin{tabular}{lcc}
\hline Temperature ${ }^{\circ} \mathrm{C}$ & Ground fig, $D_{\text {eff }} \mathrm{m}^{2} \mathrm{~s}^{-1}$ & Half cut figs, $D_{\text {eff }} \mathrm{m}^{2} \mathrm{~s}^{-1}$ \\
\hline 45 & $5.15 \times 10^{-10}$ & $5.88 \times 10^{-10}$ \\
55 & $9.96 \times 10^{-10}$ & $1.66 \times 10^{-09}$ \\
65 & $1.07 \times 10^{-09}$ & $2.08 \times 10^{-09}$ \\
\hline
\end{tabular}

TABLE 2: Activation energy $\left(E_{a}\right)$ for dehydrated ground figs and half cut figs.

\begin{tabular}{lc}
\hline Ground figs, $E_{a}\left(\mathrm{~kJ} \mathrm{~mol}^{-1}\right)$ & Half cut figs, $E_{a}\left(\mathrm{~kJ} \mathrm{~mol}{ }^{-1}\right)$ \\
\hline 33.21 & 56.86 \\
\hline
\end{tabular}

temperatures and fig appearance varied from $5.15 \times 10^{-10}$ to $1.07 \times 10^{-9} \mathrm{~m}^{2} \mathrm{~s}^{-1}$ for ground figs and from $5.88 \times 10^{-10}$ to $2.08 \times 10^{-9} \mathrm{~m}^{2} \mathrm{~s}^{-1}$ for half-cut figs (Table 1), observing that $D_{\text {eff }}$ increased with drying temperature. These $D_{\text {eff }}$ data agree with those reported for figs var. Kymi cut lengthwise from $8.4 \times 10^{-10}$ to $1.13 \times 10^{-9}$ [25] and for figs var. Tsapela with and without skin (i.e., $3.97 \times 10^{-10}$ and $7.8 \times 10^{-10} \mathrm{~m}^{2} \mathrm{~s}^{-1}$ ), respectively [20].

For other foodstuffs, we have $D_{\text {eff }}$ for dehydrated spinach leaves varying from $6.59 \times 10^{-10}$ to $1.927 \times 10^{-9}$ [40]; for sliced onions, $3.33 \times 10^{-9}$ and $8.55 \times 10^{-9} \mathrm{~m}^{2} \mathrm{~s}^{-1}$ at $30^{\circ}$ and $60^{\circ} \mathrm{C}$, respectively [12]; for garlic slices, $2.524 \times 10^{-10} \mathrm{~m}^{2} \mathrm{~s}^{-1}$ at $2 \mathrm{~mm}$ thickness and $50^{\circ} \mathrm{C}$ to $7.566 \times 10^{-10} \mathrm{~m}^{2} \mathrm{~s}^{-1}$ at $4 \mathrm{~mm}$ and $70^{\circ} \mathrm{C}$ [41]; for persimmon slices, $7.05 \times 10^{-11}$ to $2.34 \times 10^{-10} \mathrm{~m}^{2} \mathrm{~s}^{-1}$ [13]; for jujube fruit, $1.15 \times 10^{-10}$ to $5.19 \times 10^{-10} \mathrm{~m}^{2} \mathrm{~s}^{-1}$ [14]; for olive pomace drying, from $1.25 \times 10^{-9}$ to $6.30 \times$ $10^{-9} \mathrm{~m}^{2} \mathrm{~s}^{-1}$ [16]. All these $D_{\text {eff }}$ values lie within the general range of $10^{-11}$ to $10^{-9} \mathrm{~m}^{2} \mathrm{~s}^{-1}$ reported for food materials [42].

Logarithms for diffusivities were calculated and plotted against the reciprocal temperature in order to get the slopes and to estimate the activation energy $\left(E_{a}\right)\left(\mathrm{kJ} \mathrm{mol}^{-1}\right)$. Obtained values varied from $33.21 \mathrm{~kJ} \mathrm{~mol}^{-1}$ for ground figs to $56.86 \mathrm{~kJ} \mathrm{~mol}^{-1}$ for half-cut dehydrated figs (Table 2). The $E_{a}$ values are similar to those reported by Babalis and Belessiotis [25], with values ranging from $30.81 \mathrm{~kJ} \mathrm{~mol}^{-1}$ at air velocity of $1 \mathrm{~m} \mathrm{~s}^{-1}$ to $48.47 \mathrm{~kJ} \mathrm{~mol}^{-1}$ at $3 \mathrm{~m} \mathrm{~s}^{-1}$. The $E_{a}$ for other foodstuffs such as blanched and fresh persimmon slices ranged from 30.64 to $43.26 \mathrm{~kJ} \mathrm{~mol}^{-1}$, respectively [13]; for jujube fruit from 34.97 to $74.20 \mathrm{~kJ} \mathrm{~mol}^{-1}$ [14]; for garlic slices from 30.424 to $36.365 \mathrm{~kJ} / \mathrm{mol}$ [41]; for olive pomace, from 26.30 to $37.63 \mathrm{~kJ} \mathrm{~mol}^{-1}$ [16].

$E_{a}$ represents the amount of energy required for a process or reaction to take place according to the Arrhenius equation. When it is applied to a drying process, $E_{a}$ may represent the energy needed to evaporate water from a food material, and its value will depend on the type, shape, that and composition of this material. The $E_{a}$ for half-cut figs was higher than for ground fig at the same air velocity of $1.4 \mathrm{~m} \mathrm{~s}^{-1}$, meaning that higher energy is required for completing the fruit dehydration. Generally, values of activation energy will range from 12 to $110 \mathrm{~kJ} \mathrm{~mol}^{-1}$ for foodstuffs [42].

3.1. Functional Properties. Results from functional properties assays in both ground and half-cut figs are shown in Tables 3 and 4 .

Total Phenolic Content (TPC). The TPC of fig samples ranged from $2.62-4.73 \mathrm{mg} \mathrm{g}^{-1}$ for half-cut figs to $3.23-3.72 \mathrm{mg} \mathrm{g}^{-1}$ for ground figs. TPC in fig samples was similar to the reports from other authors [9]. Both fig samples dehydrated at different temperatures presented significant differences $(P<$ 0.05 ) with respect to the freeze-dried fresh figs. The figs dried at $65^{\circ} \mathrm{C}$ were the samples showing the highest phenolic content. This may be explained by derivative phenolics formed as Amadori products from amino acids reacting with sugars in figs during the fruit drying process [43]. Although hydroxymethyl furfuraldehyde (HMF) is formed also from the Maillard reaction as an Amadori product [44], it did not react with the Folin reagent [10].

Total Monomeric Anthocyanin. Anthocyanin flavonoids are the most important phenolic compounds present in fig. They contribute to their characteristic dark color and have been linked to antihyperglycemic, anticancer, and antimutagenic health benefits [45]. Since they are a subcategory of phenolic compounds, the anthocyanin content of the examples analyzed was expected to follow the same trends as seen in the total phenolic assays. However, it was observed that the anthocyanin concentration was affected by the drying temperature, which was observed with the increasing value in the percentage of polymeric color. The total monomeric anthocyanin ranged from $1.12-1.42 \mathrm{mg} / 100 \mathrm{~g}$ for half-cut figs to $1.60-1.90$ in ground figs. The anthocyanin content in dehydrated half-cut samples was lower than the freeze-dried fresh figs. The drying process has resulted in significant degradation $(P<0.05)$ of anthocyanin in figs from all experimental samples at any temperatures. This effect was more noticeable at longer drying times (i.e., half-cut figs). However, there was no significant difference $(P>0.05)$ in total anthocyanin content of ground figs compared with freeze-dried figs.

Polymeric Color Percentage. The behavior of polymeric color percentage was different due to the process of drying. The polymeric color percentage ranged from 67.4-78.9 for halfcut figs to 75.7-80.9 for ground figs. In both cases, there was a significant difference $(P<0.05)$. The samples showing the highest polymeric color percentage were the half-cut figs dried at $65^{\circ} \mathrm{C}$ and the ground fig dried at $45^{\circ} \mathrm{C}$. Similar tendency may be observed in the degradation index, which reflects the same changes with drying temperature as the polymeric color and anthocyanin contents. In these experiments, the drying time was important by the levels of total anthocyanin and polymeric color percentage. Such is the case of half-cut figs, which showed significantly more degradation than ground samples. Other thermal processes as extrusion showed similar degradation of blueberry anthocyanins, 
TABLE 3: Total phenolic content, anthocyanin content, \% polymeric color, and degradation index (DI) in dehydrated ground figs.

\begin{tabular}{lcccc}
\hline $\begin{array}{l}\text { Drying } \\
\text { treatment }\end{array}$ & $\begin{array}{c}\text { Total phenolic content } \\
\mathrm{mg} \mathrm{CE} / \mathrm{g}\end{array}$ & $\begin{array}{c}\text { Anthocyanin content } \\
\text { mg C3GE/100 g }\end{array}$ & \% Polymeric color & Degradation index (DI) \\
\hline Freeze drying & $3.08 \pm 0.4^{\mathrm{a}}$ & $1.72 \pm 0.4^{\mathrm{a}}$ & $62.5 \pm 7.9^{\mathrm{a}}$ & $1.87 \pm 0.2^{\mathrm{a}}$ \\
$45^{\circ} \mathrm{C}$ & $3.35 \pm 0.2^{\mathrm{a}}$ & $1.74 \pm 0.3^{\mathrm{a}}$ & $80.9 \pm 14.8^{\mathrm{b}}$ & $7.98 \pm 0.2^{\mathrm{a}}$ \\
$55^{\circ} \mathrm{C}$ & $3.23 \pm 0.3^{\mathrm{a}}$ & $1.90 \pm 0.5^{\mathrm{a}}$ & $75.7 \pm 11.7^{\mathrm{b}}$ & $1.96 \pm 0.3^{\mathrm{a}}$ \\
$65^{\circ} \mathrm{C}$ & $3.72 \pm 0.2^{\mathrm{b}}$ & $1.60 \pm 0.1^{\mathrm{a}}$ & $79.0 \pm 2.8^{\mathrm{b}}$ & $2.04 \pm 0.1^{\mathrm{a}}$ \\
\hline
\end{tabular}

LSD $P<0.05, n=3$.

Different superscript letters in the same column indicate statistical difference.

CE: catechin equivalent.

C3GE: cyaniding-3-glucoside equivalent.

TABLE 4: Total phenolic content, anthocyanin content, \% polymeric color, and degradation index (DI) in dehydrated half cut figs.

\begin{tabular}{lcccc}
\hline $\begin{array}{l}\text { Drying } \\
\text { treatment }\end{array}$ & $\begin{array}{c}\text { Total phenolic content } \\
\text { mg CE/g }\end{array}$ & $\begin{array}{c}\text { Anthocyanin content } \\
\text { mg C3GE/100 g }\end{array}$ & \% Polymeric color & Degradation index (DI) \\
\hline Freeze drying & $3.08 \pm 0.4^{\mathrm{b}}$ & $1.72 \pm 0.4^{\mathrm{c}}$ & $62.5 \pm 7.9^{\mathrm{a}}$ & $1.87 \pm 0.2^{\mathrm{a}}$ \\
$45^{\circ} \mathrm{C}$ & $2.62 \pm 0.2^{\mathrm{a}}$ & $1.20 \pm 0.2^{\mathrm{a}}$ & $67.4 \pm 9.9^{\mathrm{a}}$ & $2.41 \pm 0.2^{\mathrm{b}}$ \\
$55^{\circ} \mathrm{C}$ & $3.13 \pm 0.3^{\mathrm{b}}$ & $1.12 \pm 0.2^{\mathrm{a}}$ & $78.4 \pm 1.4^{\mathrm{b}}$ & $2.47 \pm 0.3^{\mathrm{b}}$ \\
$65^{\circ} \mathrm{C}$ & $4.73 \pm 0.7^{\mathrm{c}}$ & $1.42 \pm 0.1^{\mathrm{b}}$ & $78.9 \pm 5.5^{\mathrm{b}}$ & $2.33 \pm 0.1^{\mathrm{b}}$ \\
\hline
\end{tabular}

LSD $P<0.05, n=3$.

Different superscript letters in the same column indicate statistical difference.

CE: catechin equivalent.

C3GE: cyanidin-3-glucoside equivalent.

TABle 5: Antioxidant activity of dried ground figs.

\begin{tabular}{lccccc}
\hline Treatment & $\begin{array}{c}\text { DPPH } \\
\mu \text { eq trolox/g fig }\end{array}$ & $\begin{array}{c}\text { DPPH }(0.2 \mathrm{mM}) \\
\mathrm{EC}_{50} \mathrm{mg}\end{array}$ & $\begin{array}{c}\text { ABTS } \\
\mu \mathrm{M} \text { eq trolox/g fig }\end{array}$ & $\begin{array}{c}\text { ABTS }(2 \mathrm{mM}) \\
\text { EC }_{50} \mathrm{mg}^{\mathrm{m}}\end{array}$ & $\begin{array}{c}\text { Ferricyanide } \\
\mu \mathrm{M} \text { eq trolox/g fig }\end{array}$ \\
\hline Freeze drying & $2.0 \pm 0.3^{\mathrm{a}}$ & $12.16 \pm 1.3^{\mathrm{b}}$ & $12.6 \pm 1.7^{\mathrm{a}}$ & $3.3 \pm 0.5^{\mathrm{a}}$ & $13.8 \pm 1.7^{\mathrm{a}}$ \\
$45^{\circ} \mathrm{C}$ & $3.4 \pm 0.3^{\mathrm{b}}$ & $8.61 \pm 0.3^{\mathrm{a}}$ & $13.2 \pm 0.5^{\mathrm{a}}$ & $3.1 \pm 0.1^{\mathrm{a}}$ & $17.0 \pm 0.5^{\mathrm{b}}$ \\
$55^{\circ} \mathrm{C}$ & $3.7 \pm 0.2^{\mathrm{b}}$ & $9.00 \pm 0.3^{\mathrm{a}}$ & $12.2 \pm 1.9^{\mathrm{a}}$ & $3.4 \pm 0.5^{\mathrm{a}}$ & $16.2 \pm 1.9^{\mathrm{b}}$ \\
$65^{\circ} \mathrm{C}$ & $3.8 \pm 0.3^{\mathrm{b}}$ & $8.00 \pm 0.2^{\mathrm{a}}$ & $13.0 \pm 0.9^{\mathrm{a}}$ & $3.1 \pm 0.1^{\mathrm{a}}$ & $16.7 \pm 0.9^{\mathrm{b}}$ \\
\hline
\end{tabular}

LSD $P<0.05, n=3$.

Different superscript letters in the same column indicate statistical difference.

TABLE 6: Antioxidant activity of dried half cut figs.

\begin{tabular}{lccccc}
\hline Treatment & $\begin{array}{c}\text { DPPH } \\
\mu \text { eq trolox/g fig }\end{array}$ & $\begin{array}{c}\text { DPPH }(0.2 \mathrm{mM}) \\
\text { EC }_{50} \mathrm{mg} \mathrm{fig}\end{array}$ & $\begin{array}{c}\text { ABTS } \\
\mu \mathrm{M} \mathrm{eq} \mathrm{trolox} / \mathrm{g} \text { fig }\end{array}$ & $\begin{array}{c}\text { ABTS (2 mM) } \\
\text { EC }_{50} \text { mg fig }\end{array}$ & $\begin{array}{c}\text { Ferricyanide } \\
\mu \mathrm{M} \mathrm{eq} \mathrm{trolox} / \mathrm{g} \text { fig }\end{array}$ \\
\hline Freeze drying & $2.0 \pm 0.3^{\mathrm{a}}$ & $12.16 \pm 1.3^{\mathrm{b}}$ & $12.6 \pm 1.7^{\mathrm{c}}$ & $3.3 \pm 0.5^{\mathrm{a}}$ & $13.8 \pm 1.7^{\mathrm{b}}$ \\
$45^{\circ} \mathrm{C}$ & $3.5 \pm 0.3^{\mathrm{b}}$ & $7.95 \pm 0.4^{\mathrm{a}}$ & $9.7 \pm 0.8^{\mathrm{a}}$ & $4.1 \pm 0.3^{\mathrm{c}}$ & $12.1 \pm 1.1^{\mathrm{a}}$ \\
$55^{\circ} \mathrm{C}$ & $3.4 \pm 0.3^{\mathrm{b}}$ & $7.54 \pm 0.7^{\mathrm{a}}$ & $11.2 \pm 1.1^{\mathrm{b}}$ & $3.6 \pm 0.3^{\mathrm{b}}$ & $14.6 \pm 1.7^{\mathrm{b}}$ \\
$65^{\circ} \mathrm{C}$ & $3.4 \pm 0.7^{\mathrm{b}}$ & $7.89 \pm 0.2^{\mathrm{a}}$ & $13.2 \pm 0.7^{\mathrm{c}}$ & $3.0 \pm 0.2^{\mathrm{a}}$ & $17.9 \pm 1.3^{\mathrm{c}}$ \\
\hline
\end{tabular}

LSD $P<0.05, n=3$.

Different superscript letters in the same column indicate statistical difference.

which might be also affected by browning and storage time [46].

Antioxidant Activity. Based on the DPPH assay, the dried figs exhibited the highest antioxidant activity with

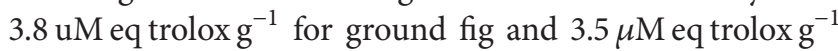
for half-cut figs in comparison with $2.0 \mu \mathrm{M}$ eq trolox $\mathrm{g}^{-1}$ of the freeze-dried fresh figs (Tables 5 and 6). This may be explained by the active degradation products from anthocyanins such as phenolic acids, which were also reported as having antioxidant activity [47]. This may also support the increased free radical scavenging capacity of dried samples compared with the fresh figs. Same trend is observed from the ABTS and MSDS-ferricyanide assays, 
with the highest values found in dried samples at $65^{\circ} \mathrm{C}$ either in ground or half-cut figs, compared with the freeze-dried fresh samples.

Despite the exposure to atmospheric oxygen and the anthocyanin loss during drying, in general, the dehydrated figs retained and enhanced the functional properties of the fresh fruit, particularly the ground figs. The differences in the retention, production, or release of total phenolics were significant, which resulted positively well correlated with the antioxidant response of the dried figs.

\section{Conclusions}

The effective moisture diffusivity coefficient of figs increased with air temperature and was always higher for half-cut figs; their calculated values $\left(5.15 \times 10^{-10}\right.$ to $\left.2.08 \times 10^{-09} \mathrm{~m}^{2} \mathrm{~s}^{-1}\right)$ are in the same order of magnitude compared to other foodstuffs. The estimated activation energy required for drying ground figs $\left(33.21 \mathrm{~kJ} \mathrm{~mol}^{-1}\right)$ is lower than that needed for half-cut figs $\left(56.86 \mathrm{~kJ} \mathrm{~mol}^{-1}\right)$. The drying process increased the total phenolic content and dropped the anthocyanin content of figs; however, it enhanced the dried figs antioxidant activity. This effect was more evident in ground figs.

\section{Abbreviations}

A: Spectrophotometric absorbance

$D_{\text {eff }}:$ Effective moisture diffusivity $\left(\mathrm{m}^{2} \mathrm{~s}^{-1}\right)$

$D_{0}$ : Effective moisture diffusivity at an infinite temperature $\left(\mathrm{m}^{2} \mathrm{~s}^{-1}\right)$

DI: Degradation Index

$E_{a}:$ Activation energy $\left(\mathrm{J} \mathrm{mol}^{-1}\right)$

L: $\quad$ Thickness of ground fig layer $(\mathrm{m})$

MR: Moisture ratio (dimensionless)

$R_{g}$ : Universal gas constant $\left(8.314 \mathrm{~J} \mathrm{~mol}^{-1} \mathrm{~K}^{-1}\right)$

$r: \quad$ Radius of the fig $(\mathrm{m})$

$T: \quad$ Drying temperature $\left({ }^{\circ} \mathrm{K}\right)$

$t$ : Drying time (min).

\section{Acknowledgments}

The first author appreciates the Mexican Council of Science and Technology (CONACyT) for Graduate Scholarship. All the authors recognize no conflict of interests directly or indirectly with commercial brands, equipment manufacturers, or company names mentioned in this publication; they deny any business, commercial, or other proprietary support, relationships, or interests with the subject of the present work.

\section{References}

[1] L. O. Dragsted, M. Strube, and J. C. Larsen, "Cancer-protective factors in fruits and vegetables: biochemical and biological background," Pharmacology and Toxicology, Supplement, vol. 72, supplement 1, pp. 116-135, 1993.

[2] R. H. Liu, "Health benefits of fruit and vegetables are from additive and synergistic combinations of phytochemicals," The
American Journal of Clinical Nutrition, vol. 78, no. 3, pp. 517S520S, 2003.

[3] H. S. Lam, A. Proctor, L. Howard, and M. J. Cho, "Rapid fruit extracts antioxidant capacity determination by Fourier transform infrared spectroscopy," Journal of Food Science, vol. 70, no. 9, pp. C545-C549, 2005.

[4] S. Martínez-Flores, J. González-Gallego, J. M. Culebras, and M. J. Tuñón, "Los flavonoides: propiedades y acciones antioxidantes," Nutrición Hospitalaria, vol. 17, no. 6, pp. 271-278, 2002.

[5] B. M. Schmidt, J. W. Erdman, and M. A. Lila, "Effects of food processing on blueberry antiproliferation and antioxidant activity," Journal of Food Science, vol. 70, no. 6, pp. S389-S394, 2005.

[6] M. E. Irget, U. Aksoy, B. Okur, A. R. Ongun, and M. Tepecik, "Effect of calcium based fertilization on dried fig (Ficus carica L. cv. Sarılop) yield and quality," Scientia Horticulturae, vol. 118, no. 4, pp. 308-313, 2008.

[7] FAO, FAOSTAT, 2010, http://faostat.fao.org/.

[8] M. K. Sadhu, "Fig," in Fruits: Tropical and Subtropical, T. K. Bose and S. K. Mitra, Eds., pp. 650-663, Naya Prokash, Calcutta, India, 1990.

[9] A. Solomon, S. Golubowicz, Z. Yablowicz et al., "Antioxidant activities and anthocyanin content of fresh fruits of common fig (Ficus carica L.)," Journal of Agricultural and Food Chemistry, vol. 54, no. 20, pp. 7717-7723, 2006.

[10] J. A. Vinson, L. Zubik, P. Bose, N. Samman, and J. Proch, "Dried fruits: excellent in vitro and in vivo antioxidants," Journal of the American College of Nutrition, vol. 24, no. 1, pp. 44-50, 2005.

[11] K. J. Chua and S. K. Chou, "Low-cost drying methods for developing countries," Trends in Food Science \& Technology, vol. 14, no. 12, pp. 519-528, 2003.

[12] C. L. Mota, C. Luciano, A. Dias, M. J. Barroca, and R. P. F. Guiné, "Convective drying of onion: kinetics and nutritional evaluation," Food and Bioproducts Processing, vol. 88, no. 2-3, pp. 115-123, 2010.

[13] I. Doymaz, "Evaluation of some thin-layer drying models of persimmon slices (Diospyros kaki L.)," Energy Conversion and Management, vol. 56, pp. 199-205, 2012.

[14] A. Motevali, A. Abbaszadeh, S. Minaei, M. H. Khoshtaghaza, and B. Ghobadian, "Effective moisture diffusivity, activation energy and energy consumption in thin-layer drying of Jujube (Zizyphus jujube Mill)," Journal of Agricultural Science and Technology, vol. 14, pp. 523-532, 2012.

[15] S. R. Sharma, S. Arora, and T. Chand, "Air drying kinetics of pomegranate seeds," International Journal of Food Engineering, vol. 7, no. 2, article 7, 2011.

[16] S. Meziane and N. Mesbahi, "Determination of moisture diffusivity and activation energy in thin layer drying of olive pomace," International Journal of Food Engineering, vol. 8, no. 3, pp. 1556-3758, 2012.

[17] I. Doymaz, "Sun drying of figs: an experimental study," Journal of Food Engineering, vol. 71, no. 4, pp. 403-407, 2005.

[18] G. Xanthopoulos, N. Oikonomou, and G. Lambrinos, "Applicability of a single-layer drying model to predict the drying rate of whole figs," Journal of Food Engineering, vol. 81, no. 3, pp. 553559, 2007.

[19] G. Xanthopoulos, S. Yanniotis, and G. Lambrinos, "Water diffusivity and drying kinetics of air drying of figs," Drying Technology, vol. 27, no. 3, pp. 502-512, 2009.

[20] G. Xanthopoulos, S. Yanniotis, and G. Lambrinos, "Study of the drying behaviour in peeled and unpeeled whole figs," Journal of Food Engineering, vol. 97, no. 3, pp. 419-424, 2010. 
[21] S. J. Babalis, E. Papanicolaou, N. Kyriakis, and V. G. Belessiotis, "Evaluation of thin-layer drying models for describing drying kinetics of figs (Ficus carica)," Journal of Food Engineering, vol. 75, no. 2, pp. 205-214, 2006.

[22] AOAC, Official Methods of Analysis, Association of Official Analytical Chemist, Washington, DC, USA, 16th edition, 1990.

[23] J. Crank, Mathematics of Diffusion, Oxford University Press, London, UK, 2nd edition, 1975.

[24] M. Riva and C. Peri, "Kinetics of sun air drying of different varieties of seedless grapes," International Journal of Food Science and Technology, vol. 21, no. 5, pp. 199-208, 1986.

[25] S. J. Babalis and V. G. Belessiotis, "Influence of the drying conditions on the drying constants and moisture diffusivity during the thin-layer drying of figs," Journal of Food Engineering, vol. 65, no. 3, pp. 449-458, 2004.

[26] C. J. Geankoplis, Transport Processes and Unit Operations, Prentice-Hall International, Englewood Cliffs, NJ, USA, 3rd edition, 1993.

[27] V. L. Singleton, R. Orthofer, and R. M. Lamuela-Raventós, "Analysis of total phenols and other oxidation substrates and antioxidants by means of folin-ciocalteu reagent," Methods in Enzymology, vol. 299, pp. 152-178, 1999.

[28] M. M. Giusti and R. E. Wrolstad, "Unit F1. 2: characterization and measurement of anthocyanins by UV-visible spectroscopy," in Handbook of Food Analytical Chemistry-Pigments, Colorants, Flavors, Texture, and Bioactive Food Components, R. E. Wrolstad, Ed., pp. F1.2.1-F1.2.13, John Wiley \& Sons, New York, NY, USA, 2005.

[29] R. E. Wrolstad, Color and Pigment Analyses in Fruit Products, Oregon Agricultural Experiment Station Bulletin, Corvallis, Ore, USA, 1976.

[30] T. Fuleki and F. J. Francis, "Quantitative methods for anthocyanins 2. Determination of total anthocyanin and degradation index for cranberry juice," Journal of Food Science, vol. 33, pp. 78-83, 1968.

[31] M. Michalczyk, R. Macura, and I. Matuszak, "The effect of airdrying, freeze-drying and storage on the quality and antioxidant activity of some selected berries," Journal of Food Processing and Preservation, vol. 33, no. 1, pp. 11-21, 2009.

[32] Y. Xiao-Ming, Y. Wei, O. Zhong-ping, M. Hai-le, L. Wei-Ming, and J. Xue-Lin, "Antioxidant and immunity activity of water extract and crude polysaccharide from Ficus carica L. fruit," Plant Foods for Human Nutrition, vol. 64, no. 2, pp. 167-173, 2009.

[33] Ì Gülcin, M. Elmastas, and H. Y. Aboul-Enein, "Antioxidant activity of clove oil-a powerful antioxidant source," Arabian Journal of Chemistry, vol. 5, pp. 489-499, 2012.

[34] K. Işil Berker, K. Güçlü, I. Tor, B. Demirata, and R. Apak, "Total antioxidant capacity assay using optimized ferricyanide/Prussian blue method," Food Analytical Methods, vol. 3, no. 3, pp. 154-168, 2010.

[35] A. Mulet, A. Berna, M. Borras, and F. Pinaga, "Effect of air flow rate on carrot drying," Drying Technology, vol. 5, no. 2, pp. 245258, 1987.

[36] R. S. Rapusas and R. H. Driscoll, "The thin-layer drying characteristics of white onion slices," Drying Technology, vol. 13, no. 8-9, pp. 1905-1931, 1995.

[37] C. Lomauro, A. Bakshi, and T. Labuza, "Moisture transfer properties of dry and semimoist foods," Journal of Food Science, vol. 50, no. 2, pp. 397-400, 1985.
[38] E. K. Akpinar, "Mathematical modelling of thin layer drying process under open sun of some aromatic plants," Journal of Food Engineering, vol. 77, no. 4, pp. 864-870, 2006.

[39] I. Doymaz, "Thin-layer drying behaviour of mint leaves," Journal of Food Engineering, vol. 74, no. 3, pp. 370-375, 2006.

[40] I. Doymaz, "Thin-layer drying of spinach leaves in a convective dryer," Journal of Food Process Engineering, vol. 32, no. 1, pp. 112125, 2009.

[41] M. Rasouli, S. Seiiedlou, H. R. Ghasemzadeh, and H. Nalbandi, "Influence of drying conditions on the effective moisture diffusivity and energy of activation during the hot air drying of garlic," Australian Journal of Agricultural Engineering, vol. 2, no. 4, pp. 96-101, 2011.

[42] N. P. Zogzas, Z. B. Maroulis, and D. Marinos-Kouris, "Moisture diffusivity data compilation in foodstuffs," Drying Technology, vol. 14, no. 10, pp. 2225-2253, 1996.

[43] M. L. Sanz, M. D. Del Castillo, N. Corzo, and A. Olano, "Formation of amadori compounds in dehydrated fruits," Journal of Agricultural and Food Chemistry, vol. 49, no. 11, pp. 5228-5231, 2001.

[44] J. L. Donovan, A. S. Meyer, and A. L. Waterhouse, "Phenolic composition and antioxidant activity of prunes and prune juice (Prunus domestica)," Journal of Agricultural and Food Chemistry, vol. 46, no. 4, pp. 1247-1252, 1998.

[45] M. Yoshimoto, S. Okuno, M. Yoshinaga, O. Yamakawa, M. Yamaguchi, and J. Yamada, "Antimutagenicity of sweetpotato (Ipomoea batatas) roots," Bioscience, Biotechnology and Biochemistry, vol. 63, no. 3, pp. 537-541, 1999.

[46] M. E. Camire, A. Chaovanalikit, M. P. Dougherty, and J. Briggs, "Blueberry and grape anthocyanins as breakfast cereal colorants," Journal of Food Science, vol. 67, no. 1, pp. 438-441, 2002.

[47] X. Yue and Z. Xu, "Changes of anthocyanins, anthocyanidins, and antioxidant activity in bilberry extract during dry heating," Journal of Food Science, vol. 73, no. 6, pp. C494-C499, 2008. 

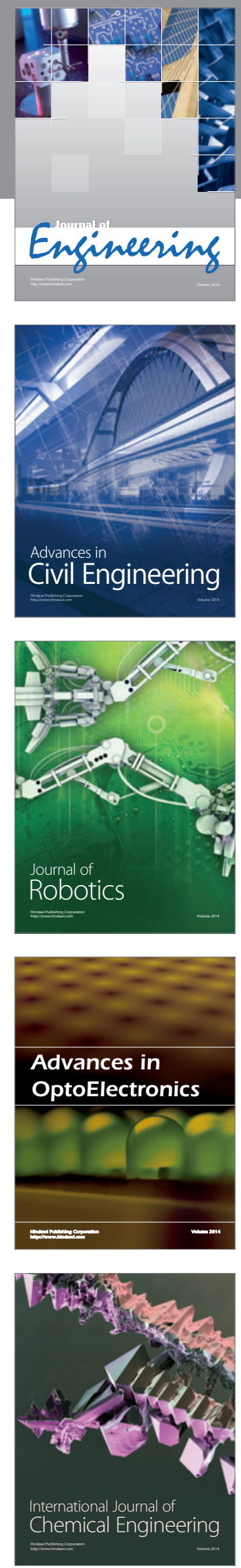

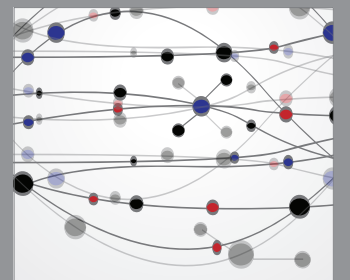

The Scientific World Journal
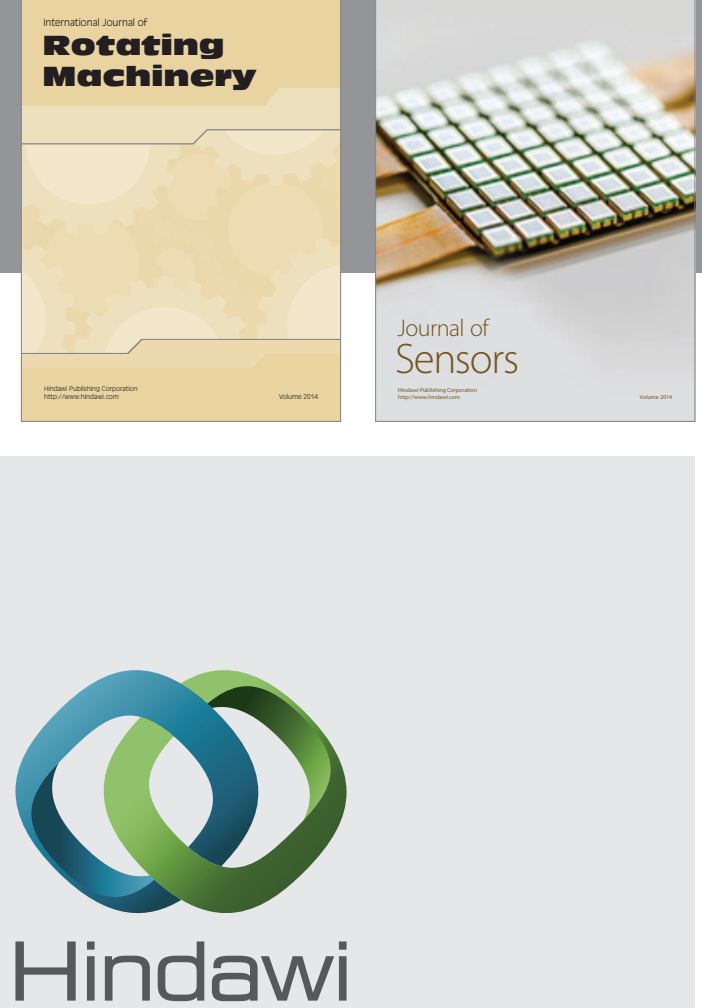

Submit your manuscripts at http://www.hindawi.com
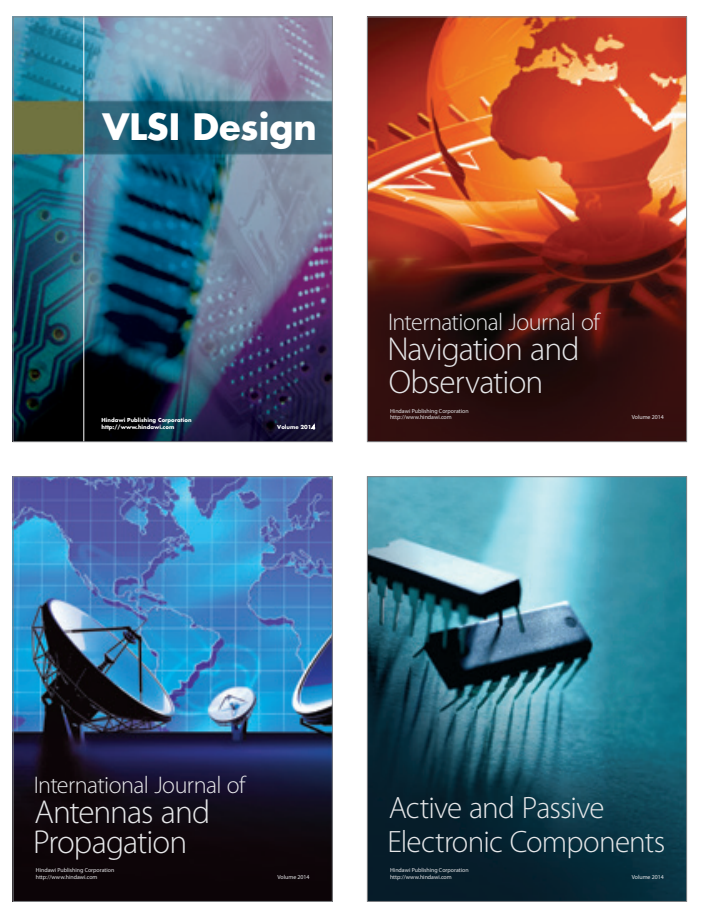
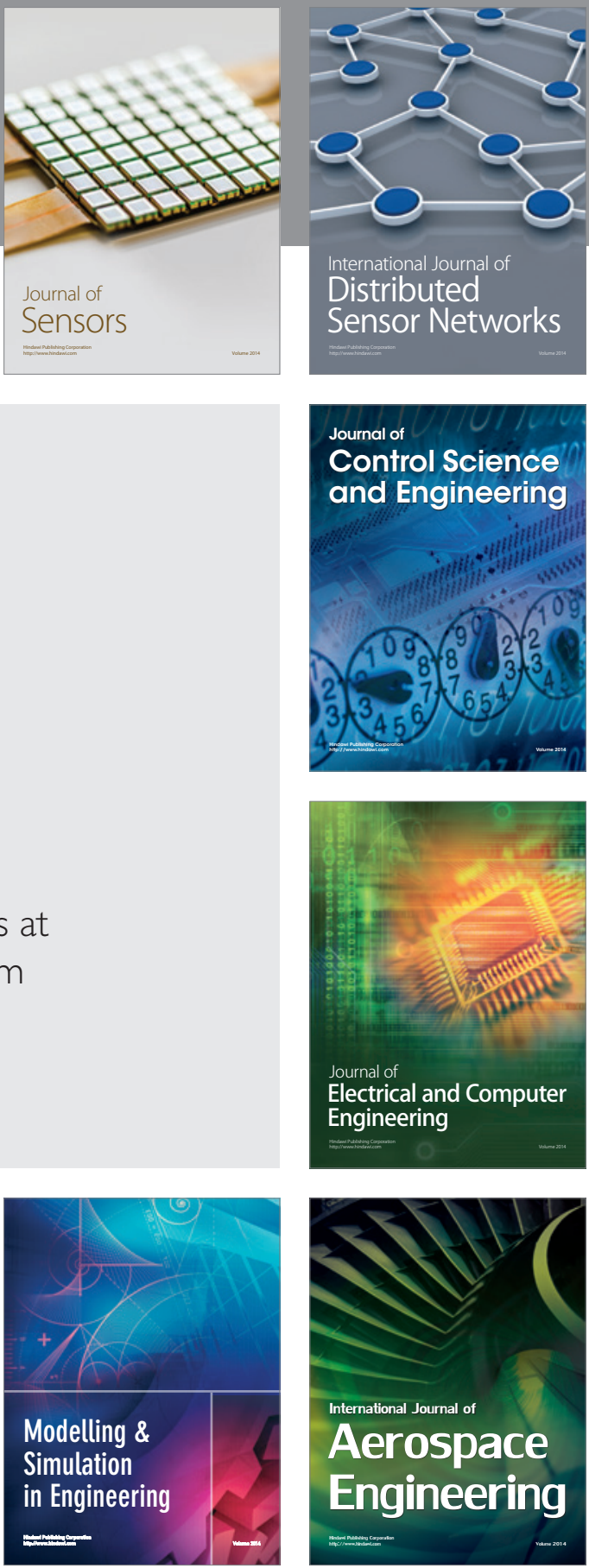

Journal of

Control Science

and Engineering
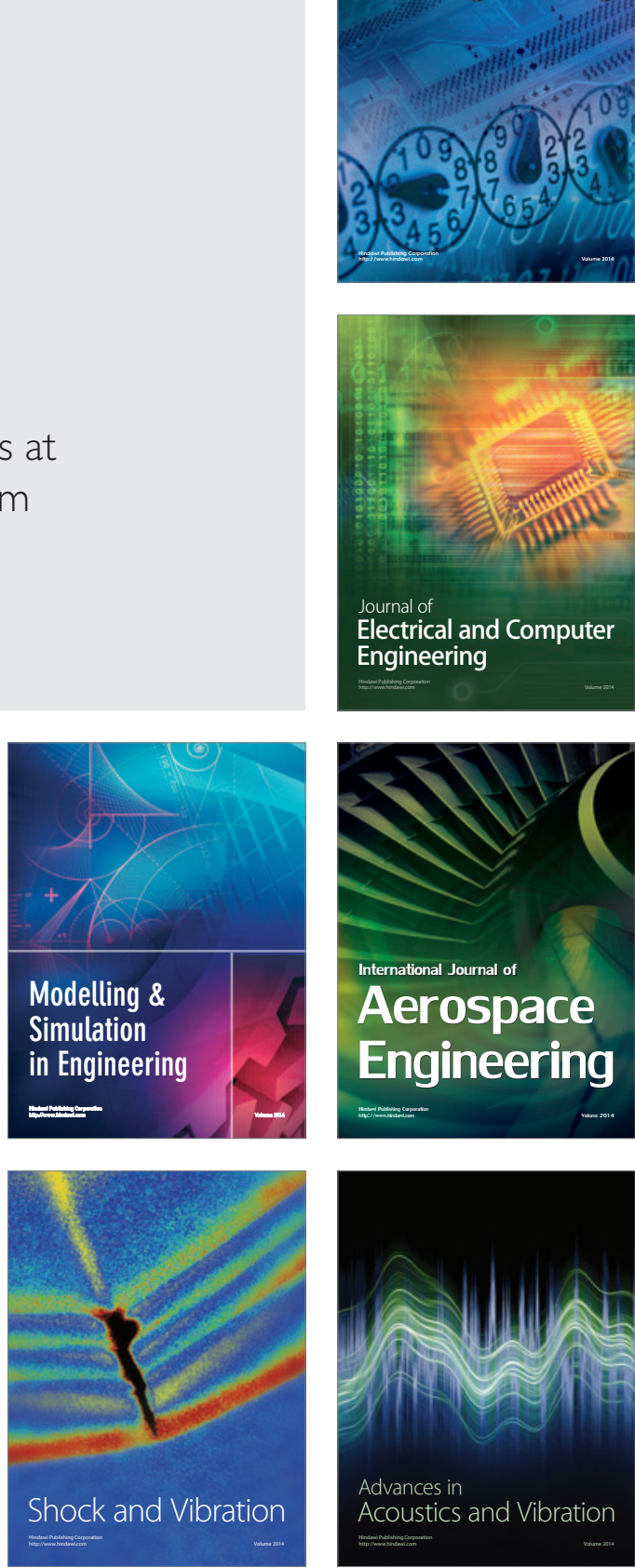